\title{
MEDICINE
}

\section{INSULIN RESISTANCE IN DRUG-SUSCEPTIBLE PULMONARY TUBERCULOSIS PATIENTS DURING THE FIRST MONTH OF ANTITUBERCULAR TREATMENT}

\author{
PhD-student Olga Mykolaivna Shvets \\ $M D$, Professor Olga Stanislavna Shevchenko \\ Ph-D Hanna Leonidivna Stepanenko \\ Ukraine, Kharkiv, Kharkiv National Medical University, \\ Department of Phthisiology and Pulmonology
}

DOI: https://doi.org/10.31435/rsglobal_wos/31082019/6650

\section{ARTICLE INFO}

Received: 19 June 2019

Accepted: 16 August 2019

Published: 31 August 2019

\section{KEYWORDS}

insulin resistance, antitubercular treatment, liver function, drugsusceptible tuberculosis.

\begin{abstract}
The study was aimed to investigate insulin resistance development in drug-susceptible newly diagnosed pulmonary tuberculosis patients. Those patients who developed insulin resistance during the 30 days of antitubercular therapy have expressed metabolic changes, that may be associated with impaired liver function due to the toxic effects of antitubercular drugs.
\end{abstract}

Citation: Olga Mykolaivna Shvets, Olga Stanislavna Shevchenko, Hanna Leonidivna Stepanenko. (2019) Insulin Resistance in Drug-Susceptible Pulmonary Tuberculosis Patients During the First Month of Antitubercular Treatment. International Academy Journal Web of Scholar. 8(38), Vol.1. doi: 10.31435/rsglobal_wos/31082019/6650

Copyright: (C) 2019 Olga Mykolaivna Shvets, Olga Stanislavna Shevchenko, Hanna Leonidivna Stepanenko. This is an open-access article distributed under the terms of the Creative Commons Attribution License (CC BY). The use, distribution or reproduction in other forums is permitted, provided the original author(s) or licensor are credited and that the original publication in this journal is cited, in accordance with accepted academic practice. No use, distribution or reproduction is permitted which does not comply with these terms.

Introduction. The issue of the bi-directional relationship between tuberculosis (TB) and diabetes mellitus (DM) is the subject of the discussion among scientists around the world [1]. Although the influence of DM as a predisposing factor causing TB is not in dispute, there are few studies dedicated to assess whether TB increases the risk of DM [2-4] and their data quite contradictory. According to some scientists, TB can lead to glucose metabolism disorders and contribute to new onset of DM. There are several thoughts trying to explain the nature of carbohydrate metabolism disorders in patients with TB. It is assumed that the pro-inflammatory response accompanying the period of infection leads to a decrease in insulin production and, as a result, to a hyperglycemic state [5, 6]. Impairment of insulin action in active TB patients may be due to releasing of stress hormones: adrenaline, cortisol and glucagon [7]. Long time persistence of Mycobacterium tuberculosis (MTB) in macrophages and adipocytes also could cause functional disorders in these cells, including insulin resistance (IR) [8]. According to other authors, the association between hyperglycemia and TB disappears after tuberculosis treatment. Thus, transient hyperglycemia is frequent during TB, and DM needs confirmation after the course of antitubercular treatment (ATT) [9]. However, a recent study reported on the development of IR in TB patients who received ATT and initially were not insulin resistant, which is contests the stress hyperglycemia hypothesis, as well as the improvement of an inflammatory state [2].

Purpose of the study: to investigate insulin resistance development during the 30 days of treatment with first-line antitubercular drugs. 
Materials and methods. The present study was performed on 56 patients aged 20 - 60 years (44 men $(78.5 \%)$ and 12 women $(21.5 \%)$ ) with new cases of pulmonary TB. Patients were examined and treated in Kharkiv Regional TB Dispensary No. 1 from 2016 to 2017. Those subjects, who had initial insulin resistance, drug-resistant TB, body mass index over $25 \mathrm{~kg} / \mathrm{m}^{2}$ and comorbid diseases (HIV/AIDS, DM, liver diseases, cancer diseases, and alcohol consumption) did not take part at the study. Standard treatment four-component scheme, which included Isoniazid, Rifampicin, Ethambutol and Pyrazinamide, were prescribed to each patient. Blood samples were collected before treatment and after 30 days of ATT. We performed an oral glucose tolerance test (OGTT) to all patients; also fasting plasma insulin level was measured. Fasting plasma glucose level was determined by the glucose oxidant method using the commercial test system of the firm "Filisit-Diagnostika" (Ukraine) on the biochemical analyzer "LabLine80 ". Fasting plasma insulin level was determined by the immune enzyme method using the commercial test systems of the company "ELISA" (EU) on the analyzer "Labline-90". Insulin resistance index was calculated by homeostasis model assessment of insulin resistance (HOMA-IR) by Matthews et al., 1985 .

We divided all subjects into groups according to the HOMA-IR values after 30 days of ATT. Group I ( $\mathrm{n}=36)$ included patients whose HOMA-IR index was below 2.7 (patients did not develop IR); Group II ( $\mathrm{n}=20$ ) included patients whose HOMA-IR index was higher than 2.7 (patients developed IR).

Statistical processing of the obtained results was carried out by analyzing the contingency tables using the StatisticaBasicAcademic 13 for Windows software package. We used the median (Me) interquartile range (Lower - lower quartile, Upper - upper quartile) and sample size (min - minimum, max maximum value). To determine the differences between groups, non-parametric statistics for unbound samples were used - Mann-Whitney U test and Wilcoxon matched pairs test for related samples (dynamic observation). For the levels of statistical significance p-values levels of less than 0.05 were taken.

Research results. In the group of patients who did not develop IR during 30 days of ATT had prevailed males $72.2 \%$ (26). Age ranged from 32 to 59, with the median of 43 years old. BMI ranged from 16.6 to 24.3 with the median of 20.41 . Two patients (5.5\%) had fibrous cavernous pulmonary TB and one (2.8\%) - miliary TB. Rest of participants had infiltrative TB. On the X-ray, bilateral injuries of the lung tissue prevailed - 28 (77.78\%). Twenty eight patients $(77.78 \%)$ had massive mycobacteria excretion.

Among those subjects who developed insulin resistance after 30 days of ATT male also had prevailed $18(90 \%)$. Age ranged from 21 to 60, with the median 35 years old. BMI ranged from 17.91 to 23.08 , the median was 19.59 . Three patients $(15 \%)$ had fibrous cavernous pulmonary TB and the rest - had infiltrative TB. On the X-ray, one-side pathologic changes prevailed - 12 (60\%). Massive mycobacteria excretion had $10(50 \%)$ patients.

Before and after 30 days of ATT, median fasting plasma glucose level in the group of non-IR - was within normal ranges $(3.6-5.5 \mathrm{mmol} / \mathrm{L}$; IDF, 2011) though, we found some insignificant increase from $3.72 \mathrm{mmol} / \mathrm{L}$ to $3.91 \mathrm{mmol} / \mathrm{L}$ during the treatment. The median level of OGTT and fasting plasma insulin level also increased insignificantly $(3.76 \mathrm{mmol} / \mathrm{L}$ vs $3.98 \mathrm{mmol} / \mathrm{L})$ and $(7.7 \mathrm{mcU} / \mathrm{ml} \mathrm{vs} 10 \mathrm{mcU} / \mathrm{ml})$ respectively. Despite of these changes, the median level of the HOMA-IR remained within the normal range and even a tendency to its decrease was revealed during the 30 days of ATT (Tab. 1).

Table 1. Dynamics of carbohydrate metabolism indices in pulmonary TB patients during the 30 days of ATT

\begin{tabular}{|c|c|c|c|c|c|}
\hline \multirow[t]{2}{*}{ Indices (units) } & \multicolumn{2}{|c|}{ Prior to treatment } & \multicolumn{2}{|c|}{ After 30 days of ATT } & \multirow{2}{*}{$\begin{array}{c}\mathrm{p}- \\
\text { value }\end{array}$} \\
\hline & Mean & Median & Mean & Median & \\
\hline \multicolumn{6}{|c|}{ Patients who didn't develop IR during the treatment (IR-) } \\
\hline Fasting plasma glucose $(\mathrm{mmol} / \mathrm{L})$ & $3.89 \pm 0.89$ & 3.72 & $4.25 \pm 0.98$ & 3.91 & \\
\hline OGTT (mmol/L) & $4.33 \pm 1.12$ & 3.76 & $4.35 \pm 1.48$ & 3.98 & \\
\hline Glycosylated hemoglobin (\%) & $4.99 \pm 1.41$ & 5.42 & $4.79 \pm 1.99$ & 4.26 & \\
\hline Fasting plasma insulin $(\mathrm{mcU} / \mathrm{ml})$ & $7.96 \pm 4.32$ & 7.7 & $9.93 \pm 6.39$ & 10 & \\
\hline HOMA-IR & $1.38 \pm 0.77$ & 1.33 & $1.41 \pm 0.83$ & 1.21 & \\
\hline \multicolumn{6}{|c|}{ Patients who developed IR during the treatment (IR+) } \\
\hline Fasting plasma glucose $(\mathrm{mmol} / \mathrm{L})$ & $3.51 \pm 0.56$ & 3.5 & $4.49 \pm 0.38$ & 4.39 & $\mathrm{p}>0.05$ \\
\hline OGTT $(\mathrm{mmol} / \mathrm{L})$ & $3.44 \pm 0.49$ & 3.33 & $5.07 \pm 0.95$ & 5.24 & $\mathrm{p}<0.05$ \\
\hline Glycosylated hemoglobin (\%) & $4.49 \pm 1.99$ & 5.3 & $5.47 \pm 2.29$ & 4.6 & $\mathrm{p}>0.05$ \\
\hline Fasting plasma insulin $(\mathrm{mcU} / \mathrm{ml})$ & $8.83 \pm 2.91$ & 8.2 & $17.72 \pm 3.48$ & 16.33 & $\mathrm{p}<0.05$ \\
\hline HOMA-IR & $1.35 \pm 0.33$ & 1.5 & $3.56 \pm 0.9$ & 4.94 & $\mathrm{p}<0.05$ \\
\hline
\end{tabular}


In the group of patients, who developed IR during the treatment initial median fasting plasma glucose level ranged from $2.78 \mathrm{mmol} / \mathrm{L}$ to $4.28 \mathrm{mmol} / \mathrm{L}$ with the median level $-3.5 \mathrm{mmol} / \mathrm{L}$. After 30 days of ATT, we observed increase of median fasting plasma glucose level to $4.39 \mathrm{mmol} / \mathrm{L}(\mathrm{min}-4.06$ $\mathrm{mmol} / \mathrm{L} ; \max -5.05 \mathrm{mmol} / \mathrm{L}$, though these changes were insignificant $(\mathrm{p}>0.05)$. But we found significant increase of median postprandial plasma glucose level during the treatment of pulmonary tuberculosis patients $(3.33 \mathrm{mmol} / \mathrm{L}$ vs $5.24 \mathrm{mmol} / \mathrm{L})$. Baseline median fasting plasma insulin level increased in 2 times: from $8.2 \mathrm{mcU} / \mathrm{ml}$ to $16.33 \mathrm{mcU} / \mathrm{ml}(\mathrm{p}<0.05)$ and significant increase in the median of HOMA-IR (1.5 vs 4.94) indicated to the development of insulin resistance in these group of patients during the ATT (Tab.1).

When compared hematological parameters, we identified significant $(p<0.05)$ difference in hemoglobin $(\mathrm{Hb})$ levels between groups. The median $\mathrm{Hb}$ level in IR-patients was $159 \mathrm{~g} / \mathrm{L}$ and ranged from $82 \mathrm{~g} / \mathrm{L}$ to $163 \mathrm{~g} / \mathrm{L}$. At the same time, the median $\mathrm{Hb}$ level in non-IR-patients was $133 \mathrm{~g} / \mathrm{L}$ and ranged from $99 \mathrm{~g} / \mathrm{L}$ to $159 \mathrm{~g} / \mathrm{L}$ (Fig.1). Though, among those patients who developed IR during ATT, the red blood cells (RBC) level ranged widely $\left(2.9-5.310^{12} / \mathrm{L}\right)$, the median was also increased significantly, compared to those who remained non-IR ( 4.9 vs. $4.110^{12} / \mathrm{L}$, respectively) $(\mathrm{p}<0.05)($ Fig.2).

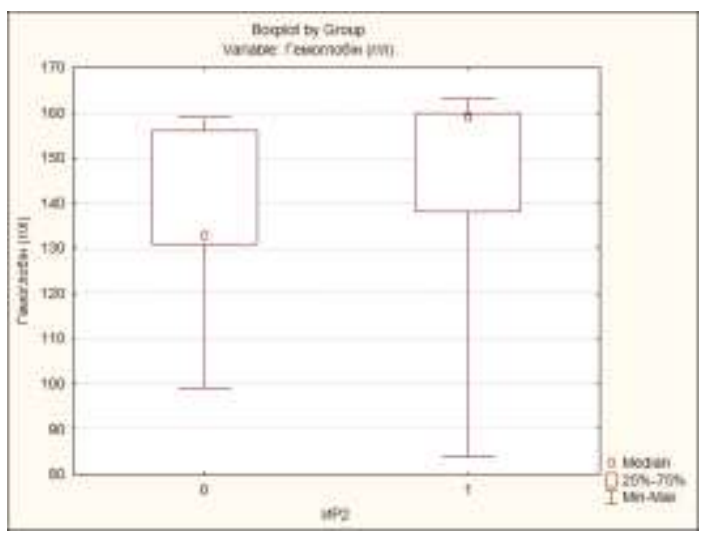

Fig. 1 Hemoglobin levels $(g / L)$ after 30 days of antitubercular ttreatment in non-IR-and IR-patients ( $p$ $=0.013, M W)$

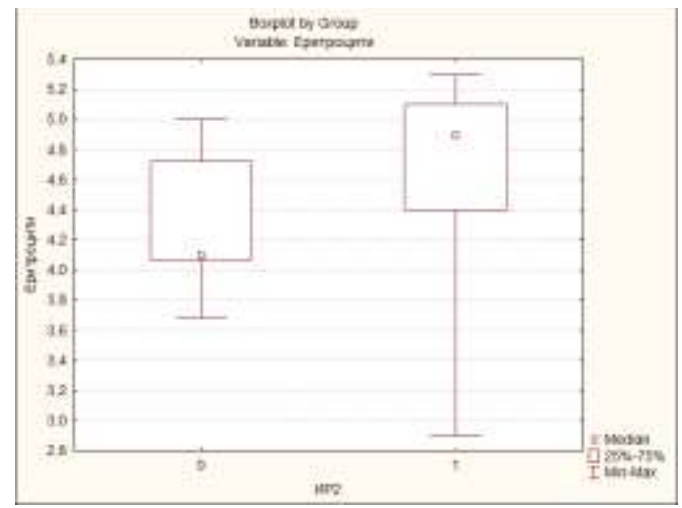

Fig. 2 Red blood cells levels $\left(10^{12} / L\right)$ after 30 days of antitubercular ttreatment in non-IR-and IRpatients $(p=0.04, M W)$

In the present study, we found an increase in RBC level in those patients, who developed IR during 30 days of ATT, compared to non-IR patients. This corresponds to data obtained in previous studies [10]. Hyperinsulinemia seems to exert its effects in erythropoiesis through the different mechanisms. The presence of the insulin receptor (INS-R) in human erythropoietic cells during all stages of development suggests that insulin acts as a co-factor in erythropoiesis [11]. Also, hyperinsulinemia seems to increase concentrations of hypoxia-inducible factor-1alpha (HIF-1 alpha). HIF-1 alpha promotes the synthesis of erythropoietin and may also mediate intestinal iron absorption [12] that explains an increase in $\mathrm{Hb}$ level in IR-patients.

Conducting the analysis of lipidogram of IR-patients, we found statistically significant changes, such as an increase in total cholesterol level, LDL-level, VLDl-level and atherogenic index which testify to the development of dyslipidemia in this patients during the treatment (Tab.2.) 
Table 2. Dynamics of lipidogram in pulmonary TB patients who developed IR during the 30 days of ATT

\begin{tabular}{|l|l|l|l|l|l|l|l|l|}
\hline & Mean & Median & Min & Max & $\begin{array}{l}\text { Lower - } \\
\text { Quartile }\end{array}$ & $\begin{array}{l}\text { Upper - } \\
\text { Quartile }\end{array}$ & Std.Dev. & p-level* \\
\hline \multicolumn{7}{|c|}{ Prior to treatment } \\
\hline $\begin{array}{l}\text { Total cholesterol, } \\
\text { mmol/L }\end{array}$ & 4.33 & 4.2 & 3.82 & 5.08 & 4.13 & 4.42 & 0.43 & \\
\hline $\begin{array}{l}\text { Triglycerides, } \\
\text { mmol/L }\end{array}$ & 1.27 & 1.26 & 1.15 & 1.44 & 1.25 & 1.28 & 0.09 & \\
\hline HDL, mmol/L & 1.16 & 1.13 & 0.98 & 1.45 & 1.01 & 1.25 & 0.17 & \\
\hline LDL, mmol/L & 2.58 & 2.42 & 2.16 & 3.26 & 2.18 & 2.92 & 0.44 & \\
\hline VLDL, mmol/L & 0.58 & 0.57 & 0.52 & 0.66 & 0.57 & 0.58 & 0.04 & \\
\hline AI & 2.78 & 2.79 & 1.89 & 3.52 & 2.66 & 3.05 & 0.54 & \\
\hline & \multicolumn{7}{|l|}{ After 30 days of ATT } \\
\hline $\begin{array}{l}\text { Total cholesterol, } \\
\text { mmol/L }\end{array}$ & 4.92 & 5.06 & 3.73 & 5.69 & 5.01 & 5.13 & 0.66 & 0.009997 \\
\hline $\begin{array}{l}\text { Triglycerides, } \\
\text { mmol/L }\end{array}$ & 1.24 & 1.27 & 1.12 & 1.37 & 1.15 & 1.31 & 0.09 & 0.047858 \\
\hline HDL, mmol/L & 1.14 & 1.17 & 0.97 & 1.26 & 1.05 & 1.26 & 0.11 & 0.128875 \\
\hline LDL, mmol/L & $\mathbf{3 . 2 1}$ & $\mathbf{3 . 3 4}$ & 2.14 & 4.01 & 3.17 & 3.41 & 0.62 & 0.008676 \\
\hline VLDL, mmol/L & 0.56 & 0.58 & 0.51 & 0.62 & 0.52 & 0.59 & 0.04 & 0.047858 \\
\hline AI & 3.31 & 3.06 & 2.84 & 3.88 & 2.97 & 3.82 & 0.45 & 0.003125 \\
\hline
\end{tabular}

*- Wilcoxon Matched Pairs Test

It is known, that liver carries out metabolism of carbohydrate, protein and fats. It synthesizes many important substances needed by the body, such as cholesterol which is packaged in the cell membrane of hepatocytes as an end product of metabolism, and then distributed to the body to be used. So, the necrosis and damage in hepatocytes might cause the release of the cholesterol from the hepatocytes into the blood stream (Santhosh et al., 2006). [6,13]. According to the results of our study, in patients who developed insulin resistance during 30 days of ATT, the dynamics to increase of the total cholesterol at significant level was observed. These changes were mainly due to increased levels of low density lipoproteins. The median level of LDL has increased during the treatment from $2.42 \mathrm{mmol} / \mathrm{L}$ to $3.34 \mathrm{mmol} / \mathrm{L}$ and even exceeded the norm $(1.6-3.2 \mathrm{mmol} / \mathrm{L})$. The median value of atherogenic index of plasma in the group of IR-patients has also increased from 2.79 to 3.06 that confirms the development of dyslipidemia and is a predictive indicator to atherosclerosis and coronary heart disease.

Also, in the group of patients who developed IR during 30 days of ATT, we revealed statistically significant changes in the dynamics of liver markers (Fig.3). It is known, that alanine aminotransferase (AlAT) is enzyme that synthesized intracellularly, and normally only a small part of this enters to the bloodstream. When the liver is damaged, as a result of liver cells destruction, this enzyme enters the bloodstream, which is detected during laboratory analysis.

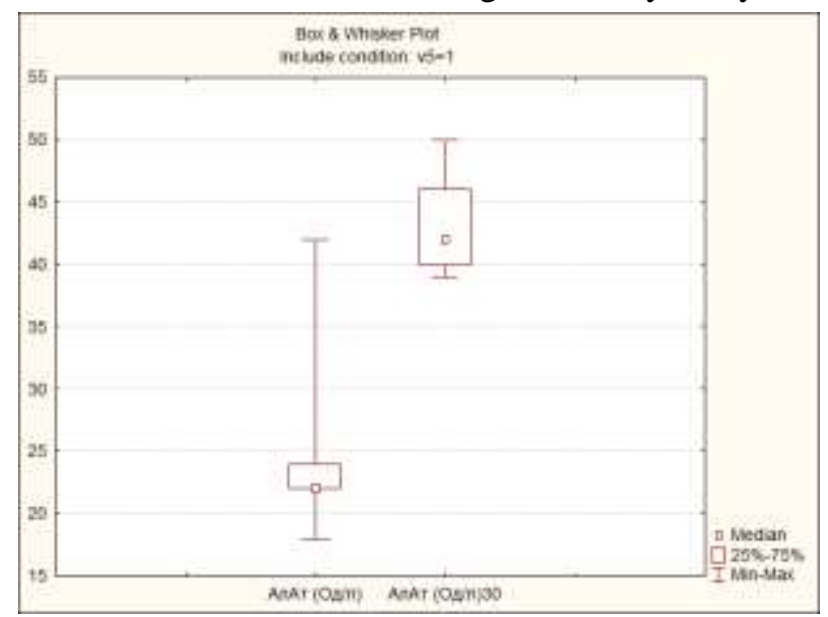

Fig.3 Dynamics of AlAT level in IR-patients during 30 days of antitubercular ttreatment ( $p=0.00039$, Wilcoxon Matched Pairs Test) 
Prior to treatment AlAT level of our participants ranged from $18 \mathrm{IU} / \mathrm{L}$ to $42 \mathrm{IU} / \mathrm{L}$ and the median was $22 \mathrm{IU} / \mathrm{L}$. During the 30 days of treatment, we revealed that the median level of AlAT in the group of IR-patients increased in 2 times $-42 \mathrm{IU} / \mathrm{L}(\mathrm{p}<0.05)(\min -39 \mathrm{IU} / \mathrm{L} ; \max -50 \mathrm{IU} / \mathrm{L})$. While in the group of patients who didn't develop IR we did not reveal such significant changes during the treatment: before treatment median level - $23 \mathrm{IU} / \mathrm{L}$ (min - $18 \mathrm{IU} / \mathrm{L} ; \mathrm{max}-26 \mathrm{IU} / \mathrm{L}$ ) vs after 30 days of ATT median level - $28 \mathrm{IU} / \mathrm{L}$ ( $\min -24 \mathrm{IU} / \mathrm{L} ; \max -30 \mathrm{IU} / \mathrm{L})$. We explain these changes by hepatotoxicity of the first-line antituberculosis drugs: isoniazid, rifampicin and pyrazinamide, which were included in the scheme of treatment.

\section{Conclusions.}

1. Newly-diagnosed patients with drug-susceptible pulmonary tuberculosis who developed insulin resistance during the 30 days of antitubercular treatment have expressed metabolic changes, in the form of impaired carbohydrate and lipid metabolism.

2. The pathogenetic basis of these changes may be an impairment of liver function, due to the influence of first-line antitubercular drugs.

\section{REFERENCES}

1. Yorke E, Atiase Y, Akpalu J, Sarfo-Kantanka O, Boima V, Dey ID. The Bidirectional Relationship between Tuberculosis and Diabetes. Tuberc Res Treat. 2017;2017:1702578. doi:10.1155/2017/1702578

2. Philips L, Visser J, Nel D, Blaauw R. The association between tuberculosis and the development of insulin resistance in adults with pulmonary tuberculosis in the Western sub-district of the Cape Metropole region, South Africa: a combined cross-sectional, cohort study. BMC Infect Dis. 2017;17(1):570. Published 2017 Aug 15. doi:10.1186/s12879-017-2657-5

3. Bershtejn, A.M., \& Kovalenko, I.G. (2010). "Metabolicheski zdorovye" litsa s ozhireniyem i metabolicheskie priznaki ozhireniya u lits s normalnoy massoy tela: chto za etim stoit? [Metabolically healthy obese subjects and metabolic signs of obesity in subjects with normal body weight: what is behind?] Problemy endokrinologii - Problems of Endocrinology, 3, 47-51 [in Russian].

4. R.M. Yasinskyi. Insulin resistance in patients with newly diagnosed pulmonary tuberculosis with different treatment outcome. Infectious Diseases. 2018; (4): 10-4

5. Pickup JC. Inflammation and activated innate immunity in the pathogensis of type 2 diabetes. Diabetes Care. 2004;27(3):813-23

6. Olga S.Shevchenko, Lilia D. Todoriko, Iryna A. Ovcharenko, Yevheniia B. Radzishevska, Olga M. Shvets, Sergiy S. Ovcharenko, Igor O. Semianiv, Volodymyr V. Vivsyannuk. Dynamics of aldosterone, connective tissue reorganization and glucose level as markers for tuberculosis treatment effectiveness. J Archives of the Balkan Medical Union. Vol. 54, Nr. 2, June, 2019. doi: 10.31688/ABMU.2019.54.2.08

7. Illuri VD, Layden BT, Aleppo G. Extreme Insulin Resistance in Critically Ill Patient With Sepsis. Clin Diabetes. 2016; 34(3):158-160. doi:10.2337/diaclin.34.3.158

8. Erol A. Visceral adipose tissue specific persistence of Mycobacterium tuberculosis may be reason for the metabolic syndrome. Med Hypotheses. 2008 Aug;71(2):222-8. doi: 10.1016/j.mehy.2008.03.028.

9. Boillat-Blanco N, Ramaiya KL, Mganga M, Minja LT, Bovet P, Schindler C, Von Eckardstein A, Gagneux S, Daubenberger C, Reither K, Probst-Hensch N. Transient Hyperglycemia in Patients With Tuberculosis in Tanzania: Implications for Diabetes Screening Algorithms. J Infect Dis. 2016 Apr 1; 213(7):1163-72. doi: 10.1093/infdis/jiv568.

10. $\mathrm{Hu}$ YH, Kuo SW, Wu DA. Relationships between hemoglobin and each component of metabolic syndrome: a special focus on elderly without medication. Int J Gerontol. 2016;10:22-27

11. Aoki I, Taniyana M, Toyama K, Homori M, Ishikawa K. Stimulatory effect of human insulin in erythroid progenitors (CFU-E and BFU-E) in human CD34 separated bone marrow cells and the relationship between insulin and erythropoetin. Stem Cells 1984;12:329-38.

12. McCarty MF. Hyperinsulinemia may boost both hematocrit and iron absorption by up-regulating activity of hypoxia-inducible factor-1alpha. Med Hypotheses 2003;61:567-73.

13. Avramoglu RK, Qiu W, Adeli K. Mechanisms of metabolic dyslipidemia in insulin resistant states: deregulation of hepatic and intestinal lipoprotein secretion. Front Biosci. 2003 Jan 1;8:d464-76. 